\title{
Kualitas Air Tanah di Sekitar TPA Km 14 Kota Palangka Raya
}

\author{
Yustani Leluno ${ }^{1,2}{ }^{*}$, Kembarawati $^{3}$, Basuki ${ }^{3}$ \\ ${ }^{1}$ Dinas Energi dan Sumberdaya Mineral Provinsi Kalimantan Tengah \\ ${ }^{2}$ Alumni Program Studi Magister Pengelolaan Sumberdaya Alam dan Lingkungan Universitas Palangka Raya \\ ${ }^{3}$ Dosen Program Studi Magister Pengelolaan Sumberdaya Alam dan Lingkungan Universitas Palangka Raya \\ *Korespondensi: Yustani Leluno (Email: lyustani@yahoo.com)
}

\begin{abstract}
The lack of clean water distribution by local water service (PDAM) of Palangka Raya city is the major reason for people around the final processing site/landfill (Tempat Pemrosesan Akhir) at Km 14 to use groundwater for their daily life. The landfill may cause pollution over groundwater known as leachate, which commonly unnoticed by its users. This study aims at assessing the quality of groundwater in that area. The groundwater was taken at different distances from the site in three rainless-days. The physical, chemical and biology parameters of groundwater are observed in the field (in situ) and analyzed in the laboratory, refers to water quality standard of Class I, according to Government Regulation No. 82 of 2001 and Minister of Health Regulation No. 32 of 2017. Public opinion on that issue is cached through interview. The results showed that the groundwater around the landfill in three rainless-days was harmless to be consumed as drinking water, and did not exceed the water quality standards stipulated by government in term of odorless, tasteless, and colorless. Some indicators also show that the groundwater meets the specified quality standards, i.e. TDS (17-68.14 mg/L), DHL (17,15-69.39 $\mu \mathrm{s})$, turbidity $(0.11-2.50 \mathrm{mg} / \mathrm{L})$, iron $(0.227-0.71 \mathrm{mg} / \mathrm{L})$, manganese $(<0.0123-0.02 \mathrm{mg} / \mathrm{L})$, coliform $(<1.8-280 \mathrm{MPN} / 100 \mathrm{ml})$, while $\mathrm{Pb}$ and $\mathrm{H}_{2} \mathrm{~S}$ were not detected. From community side, there are no any health complaints arise as long as they use the water.
\end{abstract}

\section{Keywords}

Landfill, groundwater, water quality, leachate, Palangka Raya

\section{PENDAhUluAN}

Air merupakan kebutuhan pokok setiap makhluk hidup. Manusia paling banyak memerlukan air, baik untuk keperluan sehari-hari maupun untuk segala aktivitasnya seperti air minum, irigasi, industri, perkantoran, perhotelan dan lain-lain. Menurut perhitungan WHO dinegara-negara maju setiap orang memerlukan air antara 60-120 liter per hari. Sedangkan di negara-negara berkembang, termasuk Indonesia setiap orang memerlukan air antara 30-60 liter perhari. Air bersih yang digunakan harus bebas dari kuman penyakit dan tidak mengandung bahan beracun.

Air permukaan atau sungai merupakan sumber air baku yang digunakan untuk kebutuhan air bersih saat ini. Perusahaaan Daerah Air Minum (PDAM) melakukan pengolahan air permukaaan/sungai menjadi air bersih (air baku minum). Kebutuhan akan air bersih semakin meningkat seiring dengan pertambahan penduduk. Kebutuhan akan air bersih di Kota Palangka Raya ada
26.610 rumah tangga (Badan Pusat Statistik, 2018). Sedangkan rumah tangga yang menggunakan air PDAM di Kota Palangka Raya hanya sebesar 14.591 sambungan rumah (SR) (Badan Pusat Statistik, 2019).

Keterbatasan pelayanan distribusi air bersih oleh PDAM menjadi salah satu alasan penduduk menggunakan alternatif lain untuk memenuhi kebutuhan air bersih. Air tanah merupakan alternatif utama bagi penduduk untuk mendapatkan air bersih. Penggunaan air tanah dengan pembuatan sumur gali ataupun sumur pantek tergolong mudah. Sumur gali yang memadai dan memenuhi syarat kesehatan akan melindungi sumur gali dari pencemaran sehingga mendapat air bersih yang memenuhi syarat kesehatan. Penggunaan air tanah dengan pembuatan sumur gali, sumur pantek tergolong mudah. Pembuatan sumur gali/sumur pantek dapat dilaksanakan oleh masyarakat dengan peralatan yang sederhana dan biaya yang relatif murah. Sumur gali yang memadai dan memenuhi syarat kesehatan akan melindungi sumur gali dari pencemaran sehingga 
mendapat air bersih yang memenuhi syarat kesehatan. Syarat-syarat fisik dari sumur diantaranya lokasi sumur tidak kurang dari $10 \mathrm{~m}$ dari sumber pencemar, lantai sumur sekurang-kurang berdiameter $1 \mathrm{~m}$ jaraknya dari dinding sumur dan kedap air. Saluran Pembuangan Air Limbah (SPAL) minimal 10 meter dan permanen, tinggi bibir sumur 0,8 meter, memiliki cincin (dinding) sumur minimal $3 \mathrm{~m}$ dan memiliki tutup sumur yang kuat dan rapat (Entjang, 2000).

Masyarakat di sekitar Tempat Pemrosesan Akhir (TPA) Km 14 Kota Palangka Raya menggunakan sumur gali/pantek untuk memenuhi kebutuhan air bersih. TPA adalah tempat pengumpulan sampah yang merupakan lokasi yang harus terisolir secara baik sehingga tidak menimbulkan gangguan terhadap lingkungan sekitarnya (Fajarini, 2013). Kota Palangka Raya memiliki Tempat Pemrosesan Terakhir (TPA) yang terletak di Jalan Cilik Riwut $\mathrm{Km}$ 14. Luas areal keseluruhan 10 hektar atau $100.000 \mathrm{~m}^{2}$ dengan tinggi rata-rata $10 \mathrm{~m}^{2}$ maka daya tampung TPA adalah $1.000 .000 \mathrm{~m}^{3}$. Luasan yang ada baru 6 hektar yang telah di manfaatkan sebagai operasional lahan sampah, 3 ha lahan bebas dan 1 hektar prasarana, perkantoran, kolam dan gudang. Operasional lahan sampah terdiri dari 5 zona yang Pemrosesannya menggunakan sistem controlled landfill. Metode controlled landfill merupakan perbaikan atau penyempurnaan dari system open dumping. Perbaikan ini meliputi adanya kegiatan penutupan sampah dengan lapisan tanah, fasilitas drainase, serta fasilitas pengumpulan dan pengolahan leachate. Penutupan sampah dengan tanah terdiri dari lapisan penutup antara (pada periode tertentu) serta lapisan penutup akhir setelah kapasitas TPA terpenuhi (Rini, 2018).

Salah satu fenomena bahwa TPA memberikan konstribusi penting dalam pencemaran lingkungan adalah dihasilkannya lindi (leachate) dan gas methane Lindi (leachate) adalah cairan yang merembes melalui tumpukan sampah dengan membawa materi terlarut atau tersuspensi terutama hasil proses dekomposisi materi sampah (Damanhuri, 2010). Lindi merupakan cairan yang mengandung zat padat terlarut sangat halus terdiri atas $\mathrm{Ca}^{2+}, \mathrm{Mg}^{2+}, \mathrm{Na}^{+}, \mathrm{K}^{+}, \mathrm{Fe}^{2+}, \mathrm{Cl}^{-}, \mathrm{SO}_{4}^{2-}, \mathrm{PO}^{3-}$ terlarut, $\mathrm{Zn}, \mathrm{Ni}$, dan gas $\mathrm{H}_{2} \mathrm{~S}$ yang berbau busuk. Komposisi cairan lindi dipengaruhi oleh beberapa faktor seperti jenis sampah terdeposit, jumlah curah hujan di TPA dan kondisi spesifik tempat. Menurut Resti (2017) lindi dapat meresap ke dalam tanah yang menyebabkan pencemaran tanah dan air tanah secara langsung karena lindi terdapat berbagai senyawa kimia organik dan anorganik serta sejumlah pathogen.

Air tanah yang tercemar akibat keberadaan lindi dapat menurunkan kualitas air sumur baik kualitas fisik, kimia dan mikrobiologi. Lebih jauh dikatakan pencemaran air sumur penduduk di percepat apabila sumur gali/pantek tidak memenuhi syarat kesehatan karena mempermudah proses perembesan baik pada saat hujan maupun rembesan biasa. Indikasi bahwa air tanah dangkal sudah tercemar umumnya terlihat dari perubahan atau tanda-tanda yang dapat diamati seperti perubahan warna, rasa dan bau. Ketepatan pengecekkan kualitas air untuk menentukkan tercemarnya atau tidaknya bisa dilakukan dengan uji laboratorium. Umumnya indikator yang dipakai dalam pemeriksaan air adalah dari segi fisik padatan, kekeruhan, suhu. Dari segi kimia yaitu $\mathrm{pH}$, oksigen terlarut, kebutuhan oksigen biologi, kebutuhan oksigen kimiawi, logam berat, sedangkan dari parameter biologi yang dilakukan pemeriksaan adalah mikroorganisme, baik itu bakteri ataupun jamur mikroskopik (Sumantri, 2013).

Menurut pendapat masyarakat di sekitar TPA Km 14, air sumur merupakan air kebutuhan primer karena penduduk tidak menggunakan air ledeng atau air PDAM dan secara fisik air tanah dianggap baik. Penelitian Nurraini (2011) tentang kualitas air tanah dangkal di sekitar TPA Kota Depok dilakukan pada waktu hujan dan tidak hujan (tiga hari berturut-turut tidak hujan) dengan jarak $100 \mathrm{~m}, 200 \mathrm{~m}, 300 \mathrm{~m}, 400 \mathrm{~m}$ dan $500 \mathrm{~m}$ dari pusat TPA untuk parameter TDS, DHL, Nltrat, amoniak, fosfat. Diperoleh hasil penelitian nitrat dan fosfat di atas baku mutu dan tidak dipengaruhi jarak dari TPA. Sedangkan penelitian tentang studi kualitas air tanah dangkal dan Pendapat Masyarakat Sekitar TPA Sampah Suwung Kecamatan Denpasar Selatan, Kota Denpasar dilakukan penelitian perbedaan kualitas fisik, kimia dan biologi air sumur gali dan sumur dangkal di empat lokasi dengan jarak 1-100 m, 101-200 m, 201-300 m dan 301-400 m dan pendapat masyarakat sekitar TPA. Hasil penelitian semakin jauh jarak sumur air tanah dangkal dengan TPA Sampah Suwung kualitas air tanah semakin membaik. Masyarakat yang bermukim di sekitar TPA berpendapat bahwa air tanah dangkal mengalami penurunan. Penelitian yang dilakukan oleh Nur (2015) tentang analisis kualitas air tanah di Sekitar TPA Tamangapa dengan parameter biologi bahwa pemeriksaan sampel air berdasarkan parameter biologi tidak ada pengaruh jarak TPA Tamangapa terhadap jumlah bakteri di dalam tanah.

Oleh karena itu perlu dilakukan penelitian kualitas air tanah di sekitar TPA Jalan Cilik Riwut Km 14 pada jarak yang berbeda-beda dengan waktu tidak turun hujan (tiga hari berturut-turut tidak hujan) diukur parameter fisik, kimia, dan coliform untuk mengetahui kualitas air tanah yang digunakan oleh masyarakat sekitar.

\section{METODOLOGI}

\subsection{Tempat dan Waktu Penelitian}

Lokasi penelitian dilakukan pada Tempat Pemrosesan Akhir (TPA) Jl. Cilik Riwut Km 14 Kecamatan Jekan Raya Kota Palangka Raya. Analisis kualitas air tanah di lakukan di lokasi pengambilan sampel (in situ) seperti parameter suhu, kekeruhan, daya hantar listrik, TDS dan $\mathrm{pH}$. Analisis kimia air parameter besi, mangan, timbal dan $\mathrm{H}_{2} \mathrm{~S}$ dilakukan di Laboratorium Kesehatan Provinsi Kali- 
mantan Tengah dan Laboratorium Analitik Universitas Palangka Raya. Analisa Biologi dengan parameter Total Coliform dilakukan di Laboratorium Kesehatan Provinsi Kalimantan Tengah. Wawancara dengan penduduk pada lokasi pengambilan sampel air tanah di TPA Km 14 Kecamatan Jekan Raya Kota Palangka Raya. Waktu penelitian yaitu dilakukan dari Bulan Agustus 2019 sampai dengan Desember 2019.

\subsection{Bahan dan Alat}

Bahan yang digunakan dalam penelitian ini yaitu peta lokasi penelitian untuk mengetahui lokasi penelitian, sampel air sumur air, kemudian sampel air diawetkan dengan bahan asam nitrat dan batu es, air aquadest untuk mencuci peralatan yang digunakan dalam pengukuran fisik air, serta alkohol untuk setril tangan.

Peralatan yang digunakan yaitu Global Positioning Sistem (GPS) untuk penentuan posisi dan navigasi, alat Water Prof Portable Meter untuk mengukur kualitas fisik air seperti TDS, daya hantar listrik, $\mathrm{NaCl}$ dan $\mathrm{pH}$, alat turbidimeter $100 \mathrm{~T}$ untuk mengukur kekeruhan air, botol sampel untuk tempat sampel air sumur, botol sampel untuk uji mikrobiologi, box ice dan ice pack untuk mengawetkan sampel air, kamera untuk mendokumentasi kegiatan penelitian, alat tulis untuk mencatat kegiatan penelitian.

\subsection{Desain Penelitian}

Desain Penelitian merupakan penelitian deskripsi dan wawancara dengan masyarakat yang bermukim di sekitar TPA Km 14 Palangka Raya. Sampel penelitian berupa air sumur yang di manfaatkan oleh penduduk di sekitar TPA Jl. Cilik Riwut Km 14 dengan jarak dekat 100 m, 150 m, $230 \mathrm{~m}, 240 \mathrm{~m}$, rentang pertengahan $530 \mathrm{~m}$, rentang 570 m, kemudian jarak jauh 630 m, 660 m, 745m, 780 m dengan kolam terakhir (output) pengolahan lindi di TPA $\mathrm{Km} 14$ dengan tiga hari berturut-turut tidak turun hujan kemudian dianalisa baik analisa fisik air (insitu), analisa kimia dan coliform (laboratorium). Data kualitas air parameter fisik, parameter kimia, dan coliform di bandingkan dengan pada baku mutu air Kelas I Peraturan Pemerintah Republik Indonesia Nomor 82 Tahun 2001 Tentang Pengelolaan Kualitas Air dan Pengendalian Pencemaran Air (standar air baku minum kelas I) dan Peraturan Menteri Kesehatan No. 32 Tahun 2017 tentang standar baku mutu kesehatan lingkungan dan persyaratan kesehatan air untuk keperluan higiene sanitasi. Peneliti melakukan wawancara tentang pendapat masyarakat baik masyarakat yang menggunakan air tanah, wawancara dengan stakeholder (UPT pengelolaan sampah di TPA Jl. Cilik Riwut Km 14).

\subsection{Variabel Penelitian}

Variabel yang digunakan dalam penelitian ini adalah parameter fisika, parameter kimia dan biologi air tanah, sebagaimana disajikan pada Tabel 1.
Tabel 1. Parameter sifat fisika, kimia dan biologi air

\begin{tabular}{cll}
\hline No & \multicolumn{1}{c}{ Parameter } & \multicolumn{1}{c}{ Analisis } \\
\hline 1. & Fisika & \\
& Suhu & di lokasi penelitian (insitu) \\
& Kekeruhan & di lokasi penelitian (insitu) \\
& TDS & di lokasi penelitian (insitu) \\
& $\mathrm{DHL}$ & di lokasi penelitian (insitu) \\
& $\mathrm{NaCl}$ & di lokasi penelitian (insitu) \\
2. & Kimia & \\
& $\mathrm{pH}$ & di lokasi penelitian (insitu) \\
& Besi (Fe) & di laboratorium (ex situ) \\
& Mangan (Mn) & di laboratorium (ex situ) \\
& Timbal (Pb) & di laboratorium (ex situ) \\
& $\mathrm{H}_{2} \mathrm{~S}$ & di laboratorium (ex situ) \\
3. & Biologi & \\
& Total Coliform & di laboratorium (ex situ) \\
\hline
\end{tabular}

\subsection{Metode Pengambilan Sampel}

Sampel air tanah diambil dari lokasi terdekat dengan kolam terakhir (output) pengolahan lindi di TPA. Jarak sampel dari TPA dibagi menjadi tiga klaster, yaitu rentang dekat, yaitu jarak 100, 150, 230, 240 m; rentang pertengahan, yaitu jarak 530, $570 \mathrm{~m}$; dan jarak jauh, yaitu pada jarak 630, 660, 745 dan 780 m. Sampel air tanah diambil pada tiga hari tanpa hujan berturut-turut.

Untuk uji sifat fisik, biologi, dan kimia, air diambil dari kran dari sumur gali/pantek sebanyak $1000 \mathrm{ml}$ untuk dianalisa. Pengukuran dilakukan secara in situ pada sampel air tanah untuk parameter suhu, kekeruhan, $\mathrm{DHL}$, TDS, $\mathrm{pH}, \mathrm{NaCl}$ dengan cepat dan tidak dapat diawetkan. Pengambilan sampel air tanah untuk parameter pengujian di laboratorium yaitu parameter besi, mangan, timbal, $\mathrm{H}_{2} \mathrm{~S}$ dilakukan pengawetan dengan asam nitrat kemudian dimasukkan dalam box ice. Parameter sifat fisika, kimia dan biologi yang dianalisa disajikan pada Tabel 2.

\subsection{Metode Analisis Data}

Data dianalisis secara deskripsi yang mengacu pada baku mutu air Kelas I Peraturan Pemerintah Republik Indonesia No. 82 Tahun 2001 Tentang Pengelolaan Kualitas Air dan Pengendalian Pencemaran Air (standar air baku minum kelas I) dan Peraturan Menteri Kesehatan No. 32 Tahun 2017 Tentang Standar Baku Mutu Kesehatan Lingkungan dan Persyaratan Kesehatan Air untuk keperluan higiene sanitasi. Informasi pendapat masyarakat didapatkan melalui wawancara dengan masyarakat yang memiliki dan menggunakan air tanah.

\section{HASIL}

\subsection{Kondisi TPA}

Tempat Pemrosesan Akhir (TPA) Km 14 secara astronomi terletak diantara titik koordinat $02^{\circ} 8^{\prime} 9^{\prime \prime}$ Lintang Selatan dan $113^{\circ} 48^{\prime} 40^{\prime \prime}$ Bujur Timur. TPA Km 14 
Tabel 2. Analisis parameter fisika, kimia dan biologi

\begin{tabular}{|c|c|c|c|c|}
\hline No. & Parameter & Sat & Metode /Alat & Acuan \\
\hline & Parameter Fisika & & & \\
\hline 1. & Suhu & ${ }^{\circ} \mathrm{C}$ & Pemuaian/Water Prof Portable Meter & \\
\hline 2. & Bau, Rasa, Warna & & Organoleptik & \\
\hline 3. & TDS & $\mathrm{mg} / \mathrm{L}$ & Water Prof Portable Meter & \\
\hline 4. & $\mathrm{NaCl}$ & $\mathrm{mg} / \mathrm{L}$ & Water Prof Portable Meter & \\
\hline \multirow[t]{2}{*}{5.} & Kekeruhan & NTU & T 100 & \\
\hline & Parameter Kimia & & & \\
\hline 6. & $\mathrm{pH}$ & & Potensiometrik/Water Prof Portable Meter & \\
\hline 7. & Besi & $\mathrm{mg} / \mathrm{L}$ & Spektrofotometer & SNI 06-6989.4:2009 \\
\hline 8. & Timbal & $\mathrm{mg} / \mathrm{L}$ & Spektrofotometer & SNI 06-6989.8: 2009 \\
\hline 9. & Mangan & $\mathrm{mg} / \mathrm{L}$ & Spektrofotometer & SNI 06-6989 5: 2009 \\
\hline \multirow[t]{2}{*}{10.} & $\mathrm{H}_{2} \mathrm{~S}$ & $\mathrm{mg} / \mathrm{L}$ & Spektrofotometer & Merck, 114779 \\
\hline & Parameter Biologi & & & \\
\hline 11. & Coliform & Per 100 mL & MPN & \\
\hline
\end{tabular}

terletak di Jalan Cilik Riwut Km 14 Kelurahan Bukit Tunggal, Kecamatan Jekan Raya, Kota Palangka Raya. Luasan TPA Km 14 adalah 10 ha dengan luas 6 ha telah dimanfaatkan sebagai TPA, 3 ha sebagai lahan bebas, 1 ha sebagai sarana dan prasarana perkantoran dan kolam. Luasan 6 ha terdiri dari 5 zona, yaitu zona 1 sampai dengan zona 5. TPA Km 14 Palangka Raya direncanakan dengan sistem Sanitary Landfill sebagaimana amanat UU No. 18/2008 tentang Pengelolaan Sampah, namun terkendala dengan belum adanya areal tanah mineral yang dimiliki Pemko Palangka Raya, terbatasnya sarana dan prasarana dan keterbatasan anggaran penanganan sampah.

Penanganan sampah di TPA Km 14 pada Zona 1 sampai zona 5 menggunakan sistem Controlling Landfill (menambahkan tanah urug pada sampah). Sampah yang ada menghasilkan air lindi dan gas. Penanganan air lindi pada zona 1 sampai zona 5 dengan cara mengalirkan lindi melalui pipa ke kolam pengolahan lindi. Pengolahan lindi terdiri dari 4 (empat) kolam yaitu kolam naturasi, kolam fakultatif, kolam anorganik kemudian dari kolam anorganik lindi di lepaskan ke drainase sebelah kiri badan jalan mengalir ke keluar.

Berdasarkan peta Geologi (Lampiran) batuan di TPA Km 14 termasuk dalam Formasi Dahor. Formasi Dahor terdiri atas konglomerat coklat kehitaman, agak padat, fragmen kuarsit dan basal berukuran 1 sampai dengan 3 $\mathrm{cm}$ dengan kemas terbuka yang tertanam dalam masa dasar pasir, berselingan dengan batu pasir dan batu lempung. Batu pasir berwarna kuning abu-abu, berukuran abu-abu, berukuran butir pasir sedang sampai kasar, setempat berstruktur sedimen silang siur. Batu lempung berwarna abu-abu, agak lunak karbonan dan setempat mengandung lignit tersingkap sebagai sisipan dalam batu pasir dengan kemas terbuka yang tertanam dalam masa dasar pasir, berselingan dengan batu pasir dan batu lempung. Batu lempung berwarna abu-abu, agak lunak, karbonan dan setempat mengandung lignit.
Jenis tanah di TPA Km 14 pada peta tanah termasuk dalam tanah Podsol (lampiran) mempunyai tekstur yang bersifat lempung hingga berpasir, bersifat seperti pasir yang bertekstur sedang hingga kasar. Tekstur ini bersifat lepas di bagian atas dan pejal di bagian bawah. Berwarna pucat dikarenakan ada kandungan A2 atau abu-abu di setiap jengkal ataupun butiran-butiran tanah tersebut dengan kandungan pasir kuarsa yang sangat tinggi. Memiliki tingkat keasamannya yang tinggi dengan kondisi pH 3,5 sampai 5,5 dari asam sampai asam. Topografi secara regional daerah di TPA Km 14 termasuk dalam morfologi dataran dengan ketinggian $15 \mathrm{~m}$ sampai dengan $18 \mathrm{~m}$ kurang dari $25 \mathrm{~m}$ diatas permuka laut (dpl), dengan kemiringan umum lerengnya kurang dari $2 \%$.

\subsection{Kualitas air tanah}

Penduduk di sekitar TPA Km 14 menggunakan air tanah seperti sumur gali untuk memenuhi kebutuhan mereka akan bersih baik untuk minum, memasak, dan MCK (mandi, cuci, kakus). Tiap rumah tangga memiliki air sumur gali. Analisis kualitas berdasarkan parameter Fisik, Kimia dan Biologi. Pengambilan sampel air tanah dilakukan pada musim kemarau. dapat disajikan pada Tabel 3.

Parameter yang diuji dibandingkan dengan baku mutu air Kelas I Peraturan Pemerintah Republik Indonesia No. 82 Tahun 2001 Tentang Pengelolaan Kualitas Air dan Pengendalian Pencemaran Air (standar air baku minum kelas I) dan Peraturan Menteri Kesehatan No. 32 Tahun 2017 Tentang Standar Baku Mutu Kesehatan Lingkungan dan Persyaratan Kesehatan Air untuk Keperluan Higiene Sanitasi. Hasil analisis air tanah ini di sekitar TPA Km 14 menunjukkan bahwa terdapat 2 (dua) parameter yaitu suhu dan $\mathrm{pH}$ yang tidak sesuai baku mutu Permenkes No. 32 Tahun 2017 dan PPRI No.82 Tahun 2001 Kelas 1. Hasil analisis untuk parameter Timbal $(\mathrm{Pb})$ dan $\mathrm{H}_{2} \mathrm{~S}$ pada air tanah di sekitar TPA Km 14 tidak terdeteksi (ttd). 
Tabel 3. Hasil analisis kualitas fisik, kimia dan biologi air tanah di TPA Km 14 Palangka Raya

\begin{tabular}{|c|c|c|c|c|c|c|c|c|c|c|c|c|c|c|}
\hline \multirow[t]{2}{*}{ NO } & \multirow[t]{2}{*}{ PARAMETER } & \multirow[t]{2}{*}{ SATUAN } & \multirow{2}{*}{$\begin{array}{c}\text { BMAB } \\
\text { PerMenKes } \\
32 / 2017 \\
\end{array}$} & \multirow{2}{*}{$\begin{array}{c}\text { BMAB } \\
\text { PPRI } \\
82 / 2001 \text { Klas } 1 \\
\end{array}$} & \multicolumn{10}{|c|}{ STASIUN PENGAMBILAN AIR } \\
\hline & & & & & S1 & S2 & S3 & S4 & S5 & S6 & S7 & S8 & S9 & $\mathrm{S} 10$ \\
\hline & & & & & $* 100 \mathrm{~m}$ & $* 150 \mathrm{~m}$ & $* 230 \mathrm{~m}$ & $* 240 \mathrm{~m}$ & * $530 \mathrm{~m}$ & $* 570 \mathrm{~m}$ & $* 630 \mathrm{~m}$ & $* 660 \mathrm{~m}$ & $* 745 \mathrm{~m}$ & $* 780 \mathrm{~m}$ \\
\hline 1 & $\begin{array}{l}\text { Parameter Fisika } \\
\text { Bau }\end{array}$ & & tidak berbau & & TB & TB & ТВ & ТВ & TB & TB & TB & TB & TB & TB \\
\hline 2 & Rasa & & tidakberasa & & TR & TR & TR & TR & TR & TR & TR & TR & TR & TR \\
\hline 3 & Warna & & & & TW & TW & TW & TW & TW & TW & TW & TW & TW & TW \\
\hline 4 & TDS & $\mu \mathrm{s}$ & 1000 & 1000 & 34.44 & 28.27 & 17.00 & 32.20 & 31.10 & 20.56 & 68.14 & 18.64 & 29.57 & 22.12 \\
\hline 5 & DHL & $\mathrm{mg} / 1$ & - & - & 34.94 & 29.22 & 17.15 & 32.71 & 31.81 & 21.13 & 69.39 & 18.97 & 30.25 & 22.60 \\
\hline 6 & $\mathrm{NaCl}$ & NTU & $\begin{array}{c}- \\
\text { suhu udara } \pm\end{array}$ & - & 39.90 & 33.58 & 23.91 & 37.01 & 36.52 & 27.36 & 69.39 & 25.64 & 32.93 & 27.33 \\
\hline 7 & Suhu & $\mathrm{C}$ & 3 & suhu udara \pm 3 & 33 & 31.1 & 32.5 & 31.8 & 32.3 & 32.0 & 35.5 & 33.80 & 26.6 & 24 \\
\hline 8 & $\begin{array}{l}\text { Kekeruhan } \\
\text { Parameter Kimia }\end{array}$ & & 25 & - & 0.11 & 0.15 & 1.40 & 0.12 & 2.50 & 0.85 & 2.04 & 1.27 & 0.32 & 0.88 \\
\hline 9 & $\mathrm{pH}$ & & $6,5-8,5$ & $6-9$ & 3.83 & 4.11 & 4.04 & 3.46 & 3.82 & 3.56 & 4.29 & 3.51 & 6,14 & 4.87 \\
\hline 10 & $\mathrm{Fe}$ & $\mathrm{mg} / \mathrm{l}$ & 1 & 0,3 & 0,71 & 0,642 & 0,364 & 0,357 & 0,227 & 0,258 & 0,741 & 0,635 & 0,29 & 0,41 \\
\hline 11 & Mangan & $\mathrm{mg} / \mathrm{l}$ & 0,05 & 1 & $<0,0123$ & $<0,0124$ & $<0,0125$ & $<0,0126$ & $<0,0127$ & $<0,0128$ & $<0,0129$ & $<0,0130$ & 0,01 & 0,02 \\
\hline 12 & Timbal & $\mathrm{mg} / \mathrm{l}$ & 0,5 & 0,03 & $\mathrm{ttd}$ & $\mathrm{ttd}$ & $\mathrm{ttd}$ & $\mathrm{ttd}$ & $\mathrm{ttd}$ & $\mathrm{ttd}$ & $\mathrm{ttd}$ & $\mathrm{ttd}$ & $\mathrm{ttd}$ & $\mathrm{ttd}$ \\
\hline 13 & $\mathrm{H} 2 \mathrm{~S}$ & $\mathrm{mg} / \mathrm{l}$ & - & 0,002 & $\mathrm{ttd}$ & $\mathrm{ttd}$ & $\mathrm{ttd}$ & $\mathrm{ttd}$ & $\mathrm{ttd}$ & $\mathrm{ttd}$ & $\mathrm{ttd}$ & $\mathrm{ttd}$ & $\mathrm{ttd}$ & $\operatorname{ttd}$ \\
\hline 14 & $\begin{array}{l}\text { Parameter Biologi } \\
\text { MPN Coliform }\end{array}$ & $\begin{array}{c}\text { MPN/ } 100 \\
\mathrm{ml}\end{array}$ & 50 & 1000 & $<1,8$ & 2 & 140 & $<1,8$ & 4,5 & $<1,8$ & 82 & 280 & $<1,8$ & $<1,8$ \\
\hline
\end{tabular}

Keterangan:

BMAB : bahan mutu air bersih

ttd : tidak terdeteksi oleh alat instrumen

* $\quad$ : jarak sumur masyarakat dengan outlet pengolahan lindi

Jenis batuan sangat berperan dalam meredam pencemaran dari air lindi, kemampuan meredam tersebut mencakup permeabilitas, daya infiltrasi, kemampuan absorsi batuan dan lain lain. Material batuan yang berbutir halus seperti batu lempung, napal dibandingkan batuan dengan material yang berbutir besar ataupun kristalin. Batuan yang telah padu atau padat lebih baik dari pada batuan yang masih bersifat lepas.

\section{PEMBAHASAN}

\subsection{Kualitas Parameter Fisik Air Tanah}

Parameter fisik untuk bau, rasa dan warna secara fisik terlihat keseluruhan air sampel berwana bening tidak berwarna. Air tanah secara organoleptik dapat dikatakan masih layak kosumsi sesuai syarat PPRI No. 82 Tahun 2001 dan Permenkes No. 23 Tahun 2017. Berdasarkan data pengukuran parameter TDS pada Tabel 3 menunjukkan bahwa dari sepuluh sampel nilainya berkisar antara 17-68.14 mg/l. TDS terendah di temukan pada S3 yaitu $17 \mathrm{mg} / \mathrm{l}$ dan TDS tertinggi pada S7 yaitu $68,14 \mathrm{mg} / \mathrm{l}$. Kondisi tersebut masih sesuai dengan TDS yang direkomendasi oleh baku mutu air Kelas I PP RI No. 82 Tahun 2001 dan PerMenKes No. 32 Tahun 2017 yaitu $1000 \mathrm{mg} / \mathrm{l}$.

Nilai TDS tidak dipengaruhi pada jarak titik sampel yang dekat ataupun jauh dari kolam terakhir pengolahan lindi (Gambar 4). Hal ini menandakan nilai TDS di sumur penduduk sekitar TPA Km 14 hingga radius 780 m masih di bawah baku mutu.

Parameter fisik untuk pengukuran daya hantar listrik (DHL) dan $\mathrm{NaCl}$ Daya Hantar Listrik (DHL) adalah kemampuan air untuk menghantarkan arus yang dipengaruhi oleh garam-garam yang terlarut yang dapat terionisasi.
DHL di pengaruhi oleh jenis ion, valensi dan konsentrasi Daya hantar listrik memiliki kecenderungan akan meningkat apabila terdapat ion-ion $\mathrm{Cl}^{-}, \mathrm{Na}^{+}$yang semakin besar pada suatu larutan. Daya Hantar Listrik berhubungan dengan pergerakkan suatu ion di dalam larutan ion yang mudah bergerak mempunyai daya hantar listrik yang besar (Meilasari dan Pandabesei, 2013). Berdasarkan data pengukuran parameter DHL\& $\mathrm{NaCl}$ di Tabel 3 memperlihatkan bahwa pada sepuluh sampel Daya Hantar Listrik pada sampel air berkisar antara 17.15-69.39. Nilai DHL terendah pada S3 $(230 \mathrm{~m})$ yaitu 17,15 dan $\mathrm{DHL}$ tertinggi pada S7 $(630 \mathrm{~m})$ yaitu $69,39 . \mathrm{NaCl}$ berkisar antara 23,9169,39 . Nilai $\mathrm{NaCl}$ terendah pada S3 $(230 \mathrm{~m})$ yaitu 23,91 dan $\mathrm{NaCl}$ tertinggi pada S7 $(630 \mathrm{~m})$ yaitu 69,39 .

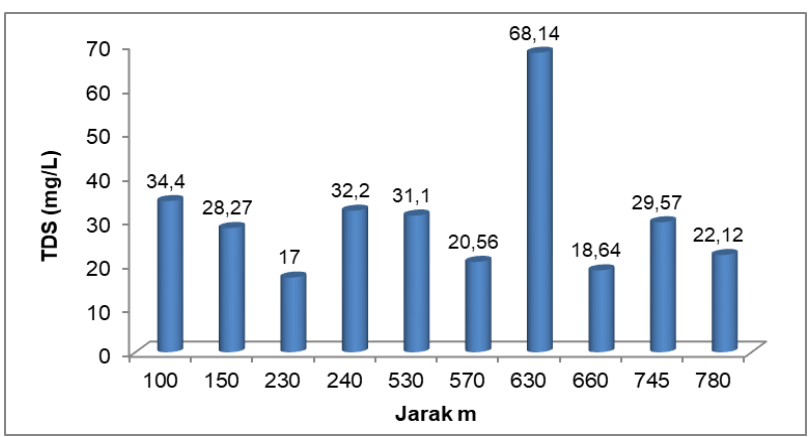

Gambar 4. Kondisi total TDS air sumur pada jarak tertentu

Sementara itu Gambar 6 menunjukkan bahwa nilai $\mathrm{DHL} \& \mathrm{NACl}$ tidak dipengaruhi pada jarak titik sampel yang dekat ataupun jauh dari kolam terakhir pengolahan lindi. Hal ini menandakan nilai DHL \& NACl di sumur penduduk sekitar TPA Km 14 hingga radius 780 meter masih di bawah baku mutu. 


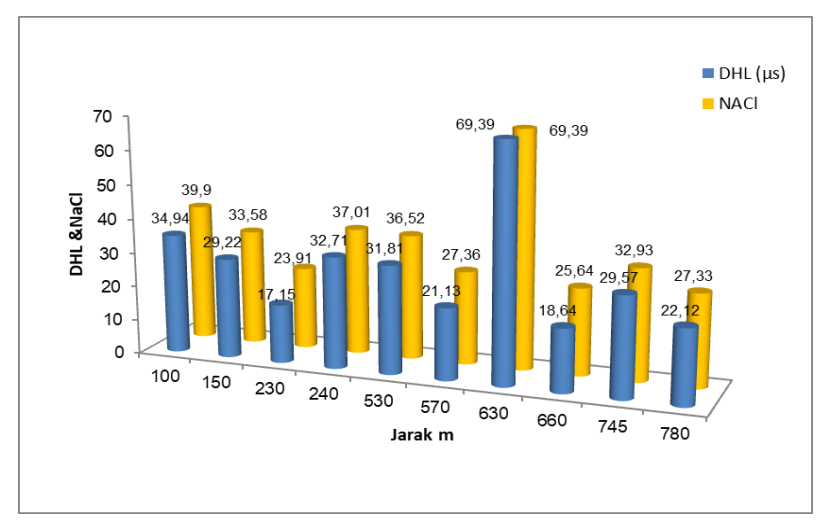

Gambar 6. Kondisi DHL \& NACl air sumur pada jarak tertentu

Suhu air secara umum dipengaruhi oleh kondisi lingkungan saat pengambilan sampel air berlangsung (Kusumawati, 2012). Hasil pengukuran suhu air secara insitu pada sampel air tanah pada Tabel 3 berkisar antara $26-35.5^{\circ} \mathrm{C}$. Suhu normal lingkungan adalah $27^{\circ} \mathrm{C}$ menurut Kusumawati (2012) maka membatasi suhu air adalah di kisaran $24-30^{\circ}$ C. Pada tabel 4, diperlihatkan bahwa 8 (delapan) sampel air tanah (S1-S8) tidak sesuai baku mutu air Kelas I PPRI No. 82 Tahun 2001 dan Permenkes No.32 Tahun 2017 yaitu deviasi $\pm 3^{\circ} \mathrm{C}$ dari 10 (sepuluh) sampel air tanah. Suhu terendah di temukan pada S10 $(780 \mathrm{~m})$ yaitu $26^{\circ} \mathrm{C}$ dan suhu tertinggi pada S7 $(630 \mathrm{~m})$ yaitu $35^{\circ} \mathrm{C}$. Peningkatan temperatur yang tinggi disertai penurunan kelarutan gas dalam air seperti oksigen, karbondioksida, nitrogen dan sebagainya dapat berpengaruh terhadap proses fisika, kimia dan biologi suatu perairan (Kusumawati, 2012).

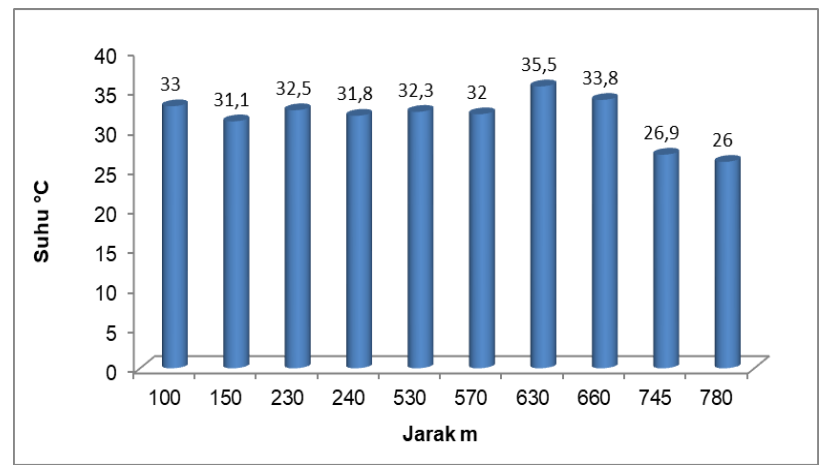

Gambar 7. Kondisi suhu air pada jarak tertentu

Gambar 7 memperlihatkan bahwa nilai suhu tidak dipengaruhi pada jarak titik sampel yang dekat ataupun jauh dari kolam terakhir pengolahan lindi. Nilai suhu di sumur penduduk sekitar TPA Km 14 hingga radius $660 \mathrm{~m}$ sesuai baku mutu. Terdapat 2 titik yang sesuai baku mutu pada radius 745-780 $\mathrm{m}$ karena pengambilan sampel air dilakukan pada waktu pagi hari.

Sementara itu Gambar 8 memperlihatkan bahwa nilai kekeruhan tidak dipengaruhi pada jarak titik sampel yang dekat ataupun jauh dari kolam terakhir pengolahan lindi. Hal ini menandakan nilai kekeruhan di sumur penduduk sekitar TPA Km 14 hingga radius 780 m masih di bawah baku mutu. Hal ini bertentangan dengan penelitian (Kusumawati, 2012) bahwa semakin jauh jarak sumur dari TPA maka kandungan TSS akan menurun. Tingginya nilai kekeruhan disebabkan adanya pengaruh komponen padatan yang terlarut dapat berupa mineral, bahanbahan organik dan berbagai jenis garam-garaman yang ada di alam atau terkandung di dalam tanah.

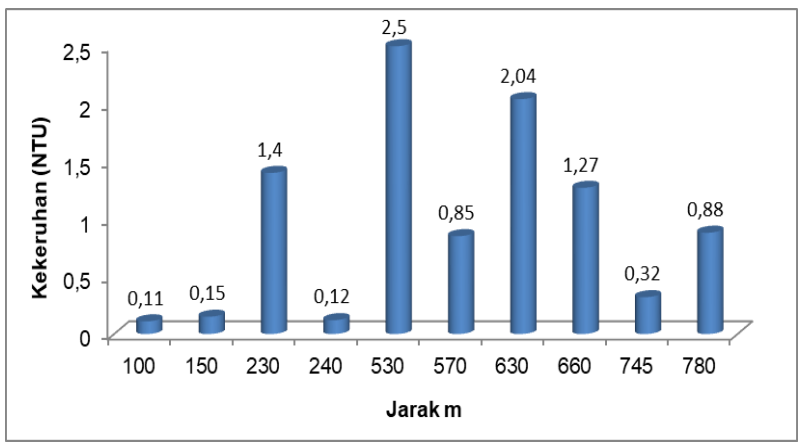

Gambar 8. Kondisi kekeruhan air pada jarak tertentu

\subsection{Kualitas Kimia Air Tanah}

Hasil pengukuran $\mathrm{pH}$ air secara in situ pada sampel air tanah pada Tabel 3 berkisar antara 3.46-6,14. pH terendah di temukan pada S2 (150 m) yaitu 4,11 dan $\mathrm{pH}$ tertinggi pada S9 $(745 \mathrm{~m})$ yaitu 6,14. Pada tabel 4, diperlihatkan bahwa 9 (sembilan) sampel air tanah (S1, S2, S3, S4, S5, S6, S7, S8 dan S10) tidak sesuai baku mutu air Kelas I PPRI No. 82 tahun 2001 yaitu 6-9 dan Permenkes No. 32 tahun 2017 yaitu yaitu 6,5-8,5.

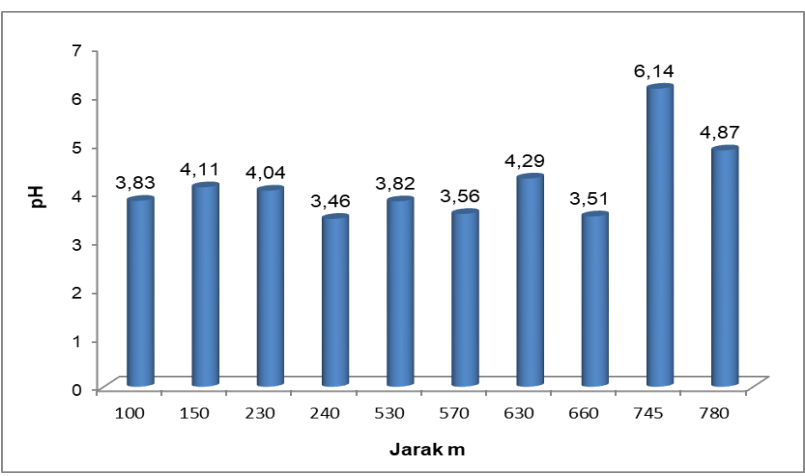

Gambar 9. Kondisi pH air pada jarak tertentu

Gambar 9 memperlihatkan bahwa nilai $\mathrm{pH}$ tidak dipengaruhi pada jarak titik sampel yang dekat ataupun jauh dari kolam terakhir pengolahan lindi. Nilai $\mathrm{pH}$ di sumur penduduk sekitar TPA Km 14 dari radius $100 \mathrm{~m}$ sampai radius $660 \mathrm{~m}$ dan radius $780 \mathrm{~m}$ tidak sesuai baku mutu. Terdapat 1 titik yang sesuai baku mutu pada radius $745 \mathrm{~m}$. Nilai pH yang asam dapat juga disebabkan jenis tanahnya penyusunnya. Jenis tanah di TPA Km 14 termasuk dalam tanah Podsol, salah satu karateristik tanah podsol yaitu memiliki tingkat keasamannya yang tinggi dengan kondisi $\mathrm{pH}$ 3,5 sampai 5,5 dari asam sampai asam. $\mathrm{pH}$ yang rendah secara alami karena tanah penyusunnya. 
Menurut penelitian yang dilakukan oleh Fajarini (2013), tinggi rendahnya $\mathrm{pH}$ pada air tidak berpengaruh pada kesehatan akan tetapi untuk air $\mathrm{pH}$ lebih kecil dari 6,5 akan menyebabkan korosi pada metal (pipa air) yang apabila kadar unsur-unsur logam tinggi dalam air maka akan unsur-unsur logam itu mudah di larutkan. $\mathrm{pH}$ lebih dari 8,5 dapat membentuk endapan (kerak) pada pipa air yang kemudian dapat bersifat racun (Fajarini, 2013).

Hasil pengukuran di laboratorium parameter Fe pada sampel air tanah pada Tabel 3 berkisar antara 0,227 mg/L $-0,71 \mathrm{mg} / \mathrm{L}$. Fe terendah di temukan pada S5 (530 m) yaitu $0,227 \mathrm{mg} / \mathrm{L}$ dan Fe tertinggi pada $\mathrm{S} 7(630 \mathrm{~m})$ yaitu 0,741 mg/L. Pada tabel 4, diperlihatkan bahwa keseluruhan sampel sesuai baku mutu air ditetapkan Permenkes No.32 Tahun 2017 yaitu 1 mg/L.

Gambar 11 mengindikasikan adanya nilai mangan yang rendah pada air sampel tanah baik sumur yang dekat dengan pengolahan lindi maupun sumur yang jauh dari pengolahan lindi. Mangan dalam jumlah kecil (0.5 $\mathrm{mg} / \mathrm{l}$ ) dalam air tidak menimbulkan gangguan. Mangan dalam jumlah yang besar $(0.5 \mathrm{mg} / \mathrm{l})$ mangan $(\mathrm{Mn})$ dalam air minum bersifat neurotoksik.

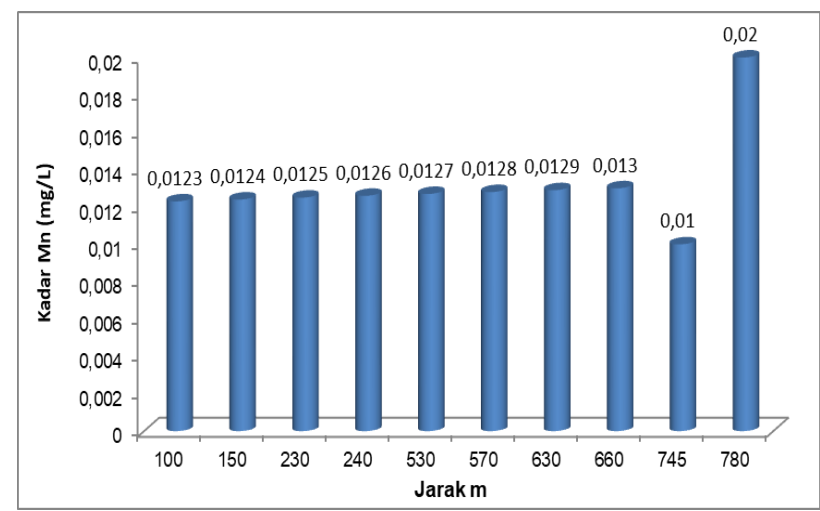

Gambar 11. Kondisi Mangan (Mn) air pada jarak tertentu

Nilai Timbal $(\mathrm{Pb})$ pada 10 (sepuluh) sampel air tanah tidak terdeteksi pada Tabel 3, kelarutan Timbal $(\mathrm{Pb})$ yang rendah dalam air tanah tidak terbaca oleh alat instrumen di Laboratorium.

Nilai Hidrogen Sulfida $\left(\mathrm{H}_{2} \mathrm{~S}\right)$ pada 10 (sepuluh) sampel air tanah tidak terdeteksi pada Tabel 3, kelarutan Hidrogen Sulfida $\left(\mathrm{H}_{2} \mathrm{~S}\right)$ yang rendah dalam air tanah tidak terbaca oleh alat intrumen di Laboratorium. Kadar Hidrogen Sulfida $\left(\mathrm{H}_{2} \mathrm{~S}\right)$ secara keseluruhan dalam sampel air berada di bawah baku mutu air Kelas I PPRI No. 82 Tahun 2001 yaitu 0,002 mg/L.

\subsection{Parameter Kualitas Biologi Air Tanah}

Hasil pengukuran di laboratorium parameter Coliform pada sampel air tanah pada Tabel 3 berkisar $<1,8-280$ $\mathrm{mg} / \mathrm{L}$. Coliform terendah di temukan pada pada S1, S4, S6, S9, S10 yaitu $<1,8 \mathrm{mg} / \mathrm{L}$ dan Coliform tertinggi pada $\mathrm{S} 7(630 \mathrm{~m})$ dan S8 $(660 \mathrm{~m})$ yaitu $280 \mathrm{mg} / \mathrm{L}$. Tingginya nilai coliform diduga karena lokasi sumur berdekatan dengan kandang babi yang memungkinkan kotoran babi mencemari tanah. Kadar coliform secara keseluruhan masih berada sesuai baku mutu Kelas I PPRI No. 82 tahun 2001 yaitu $1000 \mathrm{mg} / \mathrm{L}$.

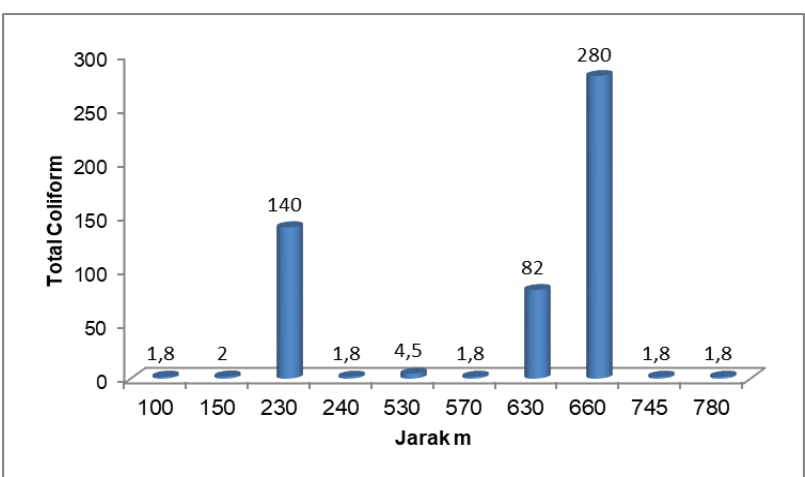

Gambar 12. Kondisi Coliform air pada jarak tertentu

Gambar 12 memperlihatkan bahwa nilai coliform tidak dipengaruhi pada jarak titik sampel yang dekat ataupun jauh dari kolam terakhir pengolahan lindi. Nilai Coliform di sumur penduduk sekitar TPA Km 14 hingga radius $780 \mathrm{~m}$.

\subsection{Pendapat Masyarat}

Pendapat masyarakat menyatakan bahwa air sumur di lingkungannya layak digunakan sebagai air minum karena air sumur tidak berwarna, tidak berbau dan tidak berasa serta tidak ada keluhan kesehatan.

\section{KESIMPULAN DAN SARAN}

Berdasarkan hasil penelitian yang dilakukan pada TPA Km 14 Palangka Raya diperoleh nilai kualitas air tanah di sekitar TPA Km 14 pada waktu tidak turun hujan dengan jarak 100, 150, 230, 240, 530, 570, 630, 660, 745 dan 780 meter dengan kolam terakhir (output) pengolahan lindi di TPA Km 14 masih layak dikosumsi sebagai air baku minum setelah diolah. Parameter pengukuran kualitas air tanah yang sesuai baku mutu air kelas I PPRI No. 82 Tahun 2001 dan Permenkes No. 32 Tahun 2017 adalah warna, bau, rasa, TDS (17-68,14 mg/ $\mathrm{L})$, daya hantar listrik $(17,15-69,39 \mu \mathrm{S})$ dan $\mathrm{NaCl}(23,91$ $69,39 \mathrm{mg} / \mathrm{L})$, kekeruhan $(0,11-2,50 \mathrm{mg} / \mathrm{L})$, nilai besi $(0,227$ $-0,71 \mathrm{mg} / \mathrm{L})$, nilai mangan $(<0,0123-0,02 \mathrm{mg} / \mathrm{L})$, nilai timbal dan sulifida $\left(\mathrm{H}_{2} \mathrm{~S}\right)$ tidak terdetektesi serta total coliform (<1,8-280 MPN/100 ml). Parameter yang tidak sesuai baku mutu air kelas I PPRI No. 82 Tahun 2001 dan Permenkes No. 32 Tahun 2017 adalah parameter suhu pada delapan (S1-S8) sampel air tanah $\left(31,1-35,5^{\circ} \mathrm{C}\right)$ dan parameter $\mathrm{pH}$ pada sembilan (S1, S2, S3, S4, S5, S6, S7, S8 dan S10) sampel air tanah 3,46-4,87).

Hasil wawancara terhadap pendapat masyarakat yang bermukim di sekitar TPA Km 14 menyatakan bahwa air tanah yang mereka gunakan secara fisik tidak berwarna, tidak berbau dan tidak berasa serta tidak ada keluhan kesehatan. 
Penelitian ini merekomendasikan perlunya dilakukan penelitian lebih lanjut terutama pada musim hujan dengan parameter fisika dan parameter kimia yang lebih lengkap. Bagi masyarakat yang bermukim di sekitar TPA $\mathrm{Km}$. 14 sebaiknya air tanah dari sumur gali atau sumur pantek di tampung terlebih dahulu. Oleh karena itu disarankan kepada masyarakat agar dapat melakukan pengecekkan rutin terhadap saluran-saluran pipa air, terutama pipa saluran air minum. Jika saluran pipa sudah mengalami kerusakan atau korosi, maka perlu dilakukan pergantian pipa yang baru sehingga air tanah aman dan layak untuk dikosumsi.

\section{DAFTAR PUSTAKA}

Badan Pusat Statistik. (2018). Palangka Raya dalam Angka 2017. Badan Pusat Statistik Palangka Raya: Palangka Raya.

Badan Pusat Statistik. (2019). Palangka Raya dalam Angka 2018. Badan Pusat Statistik Palangka Raya: Palangka Raya.

Damanhuri, E. (2010). Diktat Pengelolaan Sampah Teknik Lingkungan Institut Teknologi Bandung (ITB) Bandung.

Entjang, I. (2000). Ilmu Kesehatan Masyarakat, Bandung: PT. Citra Aditya Bakti.

Fajarini, S. (2013). Analisis Kualitas Air Tanah Masyarakat di sekitar Tempat Pembuangan Akhir (TPA sampah Kelurahan Sumur Batu Bantar Gebang Bekasi. Skripsi Program Studi Kesehatan Masyarakat, Fakultas Kedokteran dan IImu Kesehatan Universitas Islam Negeri Syarif Hidayatullah, Jakarta.

Febrina, L. and Ayuna, A. (2015). Studi penurunan kadar besi (Fe) dan mangan (Mn) dalam air tanah menggunakan saringankeramik. Jurnal Teknologi, 7 (1), 35-44.

Kusumawati, T. (2012). Kajian Degradasi Air Tanah Dangkal Akibat Air Lindi (Leachate) di Lingkungan Tempat Pembuangan Akhir Putri Cempo Surakarta. Tesis Program Studi Ilmu Lingkungan Universitas Sebelas Maret, Surakarta.

Meilasari, F dan Pandabesie, E.S. (2013). Penentuan Sebaran Lindi Berdasarkan Daya Hantar Listrik (DHL). Prosiding Seminar Nasional Manajemen Teknologi XVII. Program Studi MMT-ITS, Surabaya.

Nurraini, Y. (2011). Kualitas Air Tanah Dangkal di Sekitar Tempat Pembuangan Akhir (TPA) Cipayung Kota Depok. Skripsi Departemen Geografi, Fakultas Matematika dan Ilmu Pengetahuan Alam Universitas Indonesia, Depok.

Nur, F. (2015). Analisis Kualitas Air Tanah di Sekitar TPA Tamangapa dengan Parameter Biologi. Skripsi Program Studi Teknik Lingkungan Jurusan Teknik Sipil Universitas Hasanuddin, Makasar.

Peraturan Pemerintah Republik Indonesia No. 82 Tahun 2011 Tentang Pengelolaan Kualitas Air dan Pengendalian Pencemaran Air.

Peraturan Menteri Kesehatan No. 32 Tahun 2017 Tentang Standar Baku Mutu Kesehatan Lingkungan dan Persyaratan Kesehatan Lingkungan dan Persyaratan Kesehatan Air untuk Keperluan Higiene Sanitasi, Kolam Renang, Solus Per Aqua dan Pemandian Umum.

Sari, R. N., \& Afdal, A. (2017). Karakteristik Air Lindi (Leachate) di Tempat Pembuangan Akhir Sampah Air Dingin Kota Padang. Jurnal Fisika Unand, 6(1), 93-99.

Rini, T.S. (2018). Pengelolaan Sampah di Tempat Pemrosesan Akhir (TPA) ISBN 978-602-5888-45-8, Surabaya.

Sumantri, A. (2013). Kesehatan Lingkungan. Depok: Prenada Media Group. 